\title{
CLINICAL DISEASES AND MANIFESTATIONS OF GOATS AND CATTLE RECORDED AT TEACHING VETERINARY HOSPITAL IN CHITTAGONG VETERINARY AND ANIMAL SCIENCES UNIVERSITY
}

\author{
M. A. Parvez ${ }^{1 *}$, M. R. Faruque ${ }^{1}$, B. C. Sutradhar ${ }^{1}$, M. M. Rahman ${ }^{1}$, A. Mannan $^{2}$ and R. Khatun ${ }^{3}$ \\ ${ }^{1}$ Department of Medicine and Surgery, ${ }^{2}$ Shahedul Alam Quaderi Teaching Veterinary Hospital, Faculty of \\ Veterinary Medicine, Chittagong Veterinary and Animal Sciences University, Khulshi-4225, Chittagong \\ ${ }^{3}$ ECTAD- Bangladesh, Department of Livestock Services, District Livestock Office, Khulshi-4225, Chittagong
}

\begin{abstract}
Teaching Veterinary Hospital (TVH) in Chittagong Veterinary and Animal Sciences University (CVASU) plays an important role of public service to animal welfare since the period of 1996. There are lots of goats and cattle are recorded in this hospital every year but previously no report published on it. So this research was conducted to determine the prevalence of clinical diseases and manifestations of goats and cattle recorded at TVH in CVASU during the period of January to December 2012. A total of 3090 clinical cases (goats 2778 and cattle 312) were registered. Diagnosis of these clinical diseases and disorders were based on clinical history, clinical sign and different lab test. Medicinal cases constituted highest percentage (goats $74.66 \%$ and cattle $66.35 \%$ ) in comparison to surgical (goats $16.84 \%$ and cattle $24.04 \%$ ) cases and gynae-obstetrical (goats $8.50 \%$ and cattle $9.62 \%$ ) cases. Among the (1) medicinal cases, highest percentage was recorded with the diseases of digestive system (goats $16.85 \%$ and cattle 20.83\%) followed by parasitic diseases (goats $15.22 \%$ and cattle 12.82\%), infectious diseases (goats $11.95 \%$ and cattle 12.18\%), general systemic states (goats $7.91 \%$ and cattle 6.73\%), disease of the respiratory system (goats $9.57 \%$ and cattle $4.16 \%$ ), urinary system(goats $3.31 \%$ and cattle $1.28 \%$ ), special sense organs (goats $3.99 \%$ and cattle $1.28 \%$ ) and noninfectious diseases (goats 5.83\% and cattle 4.17\%). Among of the (2) surgical cases, general surgery (goats 11.77 and cattle 16.58\%) was higher in percentage than special (goats $3.31 \%$ and cattle $3.20 \%$ ) and orthopedic (goats $1.76 \%$ and cattle $3.85 \%$ ) surgery. Among of the gynae-obstetrical cases, gynaecological disorders were recorded higher (goats $6.98 \%$ and cattle $8.33 \%$ ) than obstetrical disorders (goats $1.51 \%$ and cattle $1.28 \%$ ). Prevalence of clinical diseases and disorders were analyzed on the basis of age, sex, breed and season. P-value $(\mathrm{P} \leq 0.05)$ was considered as significant. So that an appropriate control strategy has to be designed and applied, which helps to prevent of these disease conditions in study area.
\end{abstract}

Key words: Prevalence, clinical diseases, menifestation, goats, cattle, Chittagong

\section{INTRODUCTION}

Livestock plays an important role in the development of the traditional economy of Bangladesh. Bangladesh is a densely populated agricultural country with an acute shortage of meat and milk. There are about 22.53 million cattle and 14.69 million goats in Bangladesh (DLS, 2008-2009). They provide mainly milk, meat, draught and hides and skins as important export item. The contribution of Livestock in Gross Domestic Product (GDP) is about $16.23 \%$ in Bangladesh (BBS, 2008). Teaching Veterinary Hospital (TVH) in CVASU is one of the most important and reliable source of information about the diseases and manifestations in goats and cattle in the study area. There are some reports on clinical case records from Patuakhali Science and Technology University Veterinary Clinic, Babugonj, Barisal (Rahman et al., 2012), Chandanaish Upazila of Chittagong district, Bangladesh (Pallab et al., 2012), Ulipur Upazila Veterinary Hospital, Kurigram (Kabir et al., 2010) and Bangladesh Agricultural University Veterinary Clinic (Samad, 2001; Samad et al., 2002). This research works helps to describe the prevalence of clinical diseases and manifestations recorded in TVH in the district of Chittagong, Bangladesh during the period of one year.

\section{MATERIALS AND METHODS}

The study was conducted on 3090 animals (goats 2778 and cattle 312) with clinical cases were recorded at TVH in CVASU, in Chittagong district of Bangladesh during the period of 2012. The goats and cattle were registered with specific individual case registration number having full information of age, sex, and breed, Body Condition Score (BCS).

*Corresponding e-mail address: aparvez0445@gmail.com 


\section{A. Parvez and others}

Clinical diseases and manifestations were categorized as (1) Medicinal cases, (2) Surgical cases and (3) Gynaeobstetrical cases. Medicinal cases were subcategorized as, general systemic state, disease of the digestive system, respiratory system, urinary system, parasitic diseases, Infectious diseases, non infectious diseases and diseases of the special sense organ. Surgical cases were subcategorized as (a) general surgery includes accidental injury, wound, abscess, cysts, myiasis, hoof trimming, dog bite wound (b) special surgery includes laparotomy, dehorning, urolithiasis, caesarean section, castration, rumenotomy and hernia (c) orthopedic surgery includes external fixation by using plaster of paris and internal fixation by using intramedullary pinning, dynamic compression plate (DCP). Gynae-obstetrical cases were subcategorized as (a) gynecological disorders includes anestrous, repeat breeder syndromes, pregnancy check up and mastitis (b) Obstetrical diseases include abortion, dystocia and retain fetal membrane. Age of the goats were categorized as kid (<4month), adult (4-12 month) and old (>12 month), in case of cattle calf ( $<7$ month), adult (7-18 month) and old ( $>19$ month). Breeds of goats were based on their phenotypic characters as Black Bangle Goat (BBG), Jamunapari goats and crossbreed goats, in case of cattle local indigenous cattle breed and exotic cross breed cattle. The year was divided into three seasons namely summer (March to June), rainy (July to October) and winter (November to February) according to the climatic condition of Bangladesh. Data were collected from clinical case investigation record to Microsoft Excel2007@ @ spread sheet stored separately and percentages of clinical diseases and disorders were calculated. The collected data exported to analytical software STATA $11.2^{\circledR} 2011$. Prevalence of clinical diseases and disorders were determined and measures of association with their age, sex breed and seasons by using Chi-square test, values of $\mathrm{p} \leq 0.05$ were considered significant.

\section{RESULTS AND DISCUSSION}

A total of 3090 different clinical cases (goats 2778 and cattle 312) were registered at TVH during study the period of 2012. The total clinical cases were divided as medicinal cases constituted highest percentage (goats $74.66 \%$ and cattle $66.35 \%$ ) in comparison to surgical (goats $16.84 \%$ and cattle $24.04 \%$ ) and gynae-obstetrical (goats $8.50 \%$ and cattle $9.62 \%$ ) cases (Table 1). This observation agreed with the results of Rahman et al. (2012) who reported the highest prevalence of medicinal cases (goats $81.0 \%$ and cattle $84.1 \%$ ) in comparison to surgical (goats $17.9 \%$ and cattle11.2\%) and gynae-obstetrical (goats $1.1 \%$ and cattle $4.7 \%$ ) cases, but disagree with the findings of Samad (2001) who showed that medicinal cases (goats $76.91 \%$ and cattle $90.76 \%$ ), surgical cases (goats $19.42 \%$ and cattle 3.78\%) and gynea-obstetrical cases (goats 3.67\% and catle 5.46\%). A total of 3090 (goats 2778 and cattle 312) animals clinical diseases and disorders were recorded as the affected system, infectious and noninfectious diseases. The highest prevalence was recorded with the diseases of digestive system (goats $16.85 \%$ and cattle $20.83 \%$ ) and surgical cases (goats $16.84 \%$ and cattle $24.04 \%$ ), followed by parasitic diseases (goats $15.22 \%$ and cattle 12.82\%), infectious diseases (goats $11.95 \%$ and cattle 12.18\%), gynaeobstetrical diseases (goats $8.50 \%$ and cattle 9.62\%), general systemic state (goats 7.91 and cattle 6.73\%), respiratory system (goats $9.57 \%$ and cattle $4.16 \%$ ) while the least recorded cases were diseases of urinary system (goats $3.31 \%$ and cattle $1.28 \%$ ), noninfectious diseases (goats $5.83 \%$ and cattle $4.17 \%$ ) and diseases of special sense organ (goats $3.99 \%$ and $4.17 \%$ ) (Table 1). Therefore medicinal cases were higher in compare to surgery and gynecological disorders throughout whole country. This observations is not consistent with the results of Rahman et al. (2012) who reported digestive disorders (goats $22.9 \%$ and cattle $14.2 \%$ ), parasitic diseases (goats $20.04 \%$ and cattle $50.4 \%$ ), infectious diseases (cattle $4.6 \%$ ), respiratory disorders (goat $16.8 \%$ ) and eye infection (goats $13.5 \%$ ) but in case of infectious diseases of goats $11.8 \%$, respiratory disorders in cattle $5.5 \%$, least recorded cases like nutritional deficiency, musculo-skeletal disorders, urogenital disorders and skin diseases had similar findings of this report. In terms of digestive disorders and skin conditions, this observation is not consistent with the report of Samad et al. (2002) who reported 60.55\% digestive disorders and $14.92 \%$ skin diseases in calf. The results of the present study was not consistent with the results of Kabir et al. (2010) who recorded anorexia syndromes (goats $6.09 \%$ and cattle 3.17\%), digestive disorders (goats $8.69 \%$ and cattle $11.5 \%$ ), respiratory disorders (goats $6.96 \%$ and cattle $6.03 \%$ ) and skin diseases (goats $9.56 \%$ and cattle $6.60 \%$ ) but similar findings observed in case of viral diseases, FMD found highest in cattle and PPR in goats. The reported prevalence was not consistent with the results of Pallab et al. (2012) who observed the prevalence of digestive disorder $47.05 \%$, infectious diseases $7.84 \%$, respiratory disorders $6.20 \%$ and surgical affection $5.22 \%$ in cattle. There are variation of prevalence of clinical diseases and disorders observed due to different geographical location and study period. So that disease of the digestive system comprises highest prevalence in 
comparison to others due to most of the owners with the clinical history of loss of appetite. On the other hand parasitic cases also in higher prevalence due to owners are unaware about the routine deworming program.

Table 1. Prevalence of clinical diseases and manifestations in goats and cattle recorded at Teaching Veterinary Hospital (TVH) in CVASU during the year of 2012

\begin{tabular}{|c|c|c|}
\hline Parameters of clinical condition & Number of Goat $(\%)$ & Number of Cattle (\%) \\
\hline Weakness & $77(2.77)$ & $7(2.24)$ \\
\hline Fattening & $49(1.76)$ & $5(1.60)$ \\
\hline Idiopathic causes & $94(3.38)$ & $9(2.88)$ \\
\hline General systemic states & $220(7.91)$ & $21(6.73)$ \\
\hline Loss of appetite & $244(8.78)$ & $29(9.29)$ \\
\hline Diarrhea & $112(4.03)$ & $13(4.16)$ \\
\hline Ruminal tympany \& acidosis & $112(4.03)$ & $23(7.37)$ \\
\hline Digestive system & $468(16.85)$ & $65(20.83)$ \\
\hline Upper respiratory tract infection & $186(6.69)$ & $7(2.24)$ \\
\hline Pneumonia & $80(2.87)$ & $6(1.92)$ \\
\hline Respiratory System & $266(9.57)$ & $13(4.16)$ \\
\hline Dysuria & $51(1.83)$ & $4(1.28)$ \\
\hline Urolithiasis & $41(1.48)$ & $0(00)$ \\
\hline Urinary system & $92(3.31)$ & $4(1.28)$ \\
\hline Endoparasitic diseases & $319(11.48)$ & $25(8.01)$ \\
\hline Ectoparasitic diseases & $53(1.90)$ & $5(1.60)$ \\
\hline Protozoal diseases & $51(1.83)$ & $10(3.20)$ \\
\hline Parasitic diseases & $423(15.22)$ & $40(12.82)$ \\
\hline Viral diseases & $259(9.32)$ & $31(9.94)$ \\
\hline Bacterial diseases & $73(2.63)$ & $7(2.24)$ \\
\hline Infectious diseases & $332(11.95)$ & $38(12.18)$ \\
\hline Metabolic\& nutritional diseases & $101(3.63)$ & $7(2.24)$ \\
\hline Nervous \& Musculoskeletal system & $61(2.19)$ & $6(1.92)$ \\
\hline Non infectious diseases & $162(5.83)$ & $13(4.17)$ \\
\hline Eye infection & $57(2.05)$ & $4(1.28)$ \\
\hline Skin diseases & $54(1.94)$ & $9(2.88)$ \\
\hline Special sense organ & $111(3.99)$ & $13(4.17)$ \\
\hline 1.Total Medicinal cases & 2074 (74.66) & $207(66.35)$ \\
\hline General surgery & $327(11.77)$ & $53(16.98)$ \\
\hline Special surgery & $92(3.31)$ & $10(3.20)$ \\
\hline Orthopedic surgery & $49(1.76)$ & $12(3.85)$ \\
\hline 2. Surgical cases & $468(16.84)$ & $75(24.04)$ \\
\hline Gynecological disorders & $194(6.98)$ & $26(8.33)$ \\
\hline Obstetrical disorders & $42(1.51)$ & $4(1.28)$ \\
\hline 3. Gynae-obstetrical & $236(8.50)$ & $30(9.62)$ \\
\hline Total & $2778(100)$ & $312(100)$ \\
\hline
\end{tabular}

Goats and cattle were categorized as kid and calf, adult and old. Results showed that the prevalence of clinical diseases and disorders were highest in old animals (goats $38.0 \%$ and cattle $34.3 \%$ ) followed by adult (goats $35.5 \%$ and cattle $33.0 \%$ ) and lowest in kid and calf (goats $26.5 \%$ and cattle $32.7 \%$ ) consistent with the findings of Kabir et al. (2010) who observed that higher prevalence observed in adult and old cattle but similar prevalence found in young and adult goats. So that prevalence of clinical conditions higher in old and adult animal than young animal due to disease resistance capacity lower in older animal rather than young animal (Table 2). In case of cattle, the results showed that the prevalence of endoparasitic diseases was higher in adult cattle $10(3.20 \%)$ than calf $9(2.88 \%)$ and old cattle $6(1.92 \%)$ over ectoparasitic and protozoal diseases due to adult cattle get their infection by feeding of green roughage. In case of viral diseases FMD comprises higher in number in adult and old cattle were $12(3.85 \%)$ than young calf over other viral diseases but it was not significant. The highest 


\section{A. Parvez and others}

prevalence was found in loss of appetite in adult goats $100(3.60 \%)$ and old goats $92(3.31 \%)$ than young kids over the other condition of digestive system like diarrhea and tympani with significant $\mathrm{P}$ value $(\mathrm{P}=0.000)$.

Table 2. Age wise clinical diseases and manifestations of goats and cattle at TVH

\begin{tabular}{|c|c|c|c|c|c|c|c|c|}
\hline \multirow[b]{2}{*}{ Parameters } & \multicolumn{4}{|c|}{$\begin{array}{c}\text { Total number of goat } \mathrm{N}=2778 \\
\text { No }(\%)\end{array}$} & \multicolumn{4}{|c|}{$\begin{array}{c}\text { Total number of Cattle } \mathrm{N}=312 \\
\text { No }(\%)\end{array}$} \\
\hline & $<4$ month & $\begin{array}{l}4-12 \\
\text { month }\end{array}$ & $\begin{array}{l}>12 \\
\text { month }\end{array}$ & $\begin{array}{l}\text { P- } \\
\text { Value }\end{array}$ & $<7$ month & $\begin{array}{l}7-18 \\
\text { month }\end{array}$ & $\begin{array}{l}>19 \\
\text { month }\end{array}$ & $\begin{array}{l}\text { P- } \\
\text { Value }\end{array}$ \\
\hline Weakness & $18(0.65)$ & $21(0.75)$ & $38(1.37)$ & & $4(1.28)$ & $2(0.64)$ & $1(0.32)$ & 0.554 \\
\hline Fattening & $15(0.54)$ & $15(0.54)$ & $19(0.68)$ & 0.146 & $1(0.32)$ & $1(0.32)$ & $3(0.96)$ & \\
\hline Idiopathic & $37(1.33)$ & $27(0.97)$ & $30(1.07)$ & & $3(0.96)$ & $2(0.64)$ & $4(1.28)$ & \\
\hline Loss of appetite & $52(1.87)$ & $100(3.6)$ & $92(3.31)$ & & $5(1.60)$ & $14(4.49)$ & $10(3.2)$ & 0.923 \\
\hline Diarrhea & $46(1.66)$ & 35 (1.26) & $31(1.12)$ & $0.000 *$ & $2(0.64)$ & $7(2.24)$ & $4(1.28)$ & \\
\hline Tympani & $14(0.51)$ & $48(1.73)$ & $50(1.80)$ & & $4(1.28)$ & $9(2.88)$ & $10(3.2)$ & \\
\hline URTI $^{1}$ & $34(1.22)$ & $94(3.38)$ & $58(2.09)$ & $0.041 *$ & $3(0.96)$ & $2(0.64)$ & $2(0.64)$ & 0.692 \\
\hline Pneumonia & $20(0.72)$ & $27(0.97)$ & 33 (1.19) & & $4(1.28)$ & $1(0.32)$ & $1(0.32)$ & \\
\hline Dysuria & $22(0.79)$ & $15(0.54)$ & $14(0.50)$ & 0.428 & $2(0.64)$ & $0(0.00)$ & $2(0.64)$ & \\
\hline Urolithiasis & $18(0.65)$ & $16(0.57)$ & $7(0.25)$ & & $0(0.00)$ & $0(0.00)$ & $0(0.00)$ & \\
\hline Endoparasite & $78(2.80)$ & $107(3.8)$ & $134(4.8)$ & & $9(2.88)$ & $10(3.2)$ & $6(1.92)$ & $0.048 *$ \\
\hline Ectoparasite & $18(0.65)$ & $23(0.82)$ & $12(0.43)$ & 0.072 & $1(0.32)$ & $0(0.00)$ & $4(1.28)$ & \\
\hline Protozoa & $11(0.39)$ & $22(0.79)$ & $18(0.65)$ & & $3(0.96)$ & $6(1.92)$ & $1(0.32)$ & \\
\hline PPR & $50(1.80)$ & $109(3.9)$ & $78(2.80)$ & 0.732 & FMD (30) & wart (1) & & \\
\hline $\mathrm{CE}^{2}$ & $3(0.10)$ & $7(0.25)$ & $3(0.10)$ & & $6(1.92)$ & $12(3.85)$ & $12(3.85)$ & 0.170 \\
\hline Others (Virus) & $1(0.03)$ & $6(0.22)$ & $2(0.07)$ & & $1(0.32)$ & $0(0.00)$ & $0(0.00)$ & \\
\hline Tetanus & $11(0.39)$ & $0(0.00)$ & $3(0.10)$ & $0.000 *$ & Anthrax (3) & \& others (4) & & \\
\hline Foot rot & $1(0.03)$ & $4(0.14)$ & $8(0.29)$ & & $0(0.00)$ & $3(0.96)$ & $0(0.00)$ & 0.140 \\
\hline $\begin{array}{l}\text { Others } \\
\text { (Bacteria) }\end{array}$ & $4(0.14)$ & $23(0.82)$ & $19(0.68)$ & & $2(0.64)$ & $1(0.32)$ & $1(0.32)$ & \\
\hline $\mathrm{MN}^{3}$ & $25(0.90)$ & $36(1.29)$ & $40(1.43)$ & $0.03 *$ & $3(0.96)$ & $1(0.32)$ & $3(0.96)$ & 0.296 \\
\hline Mus-Ner ${ }^{4}$ & $26(0.94)$ & $21(0.76)$ & $14(0.50)$ & & $5(1.60)$ & $0(0.00)$ & $1(0.32)$ & \\
\hline Eye infection & $16(0.57)$ & $17(0.61)$ & $24(0.86)$ & 0.964 & $2(0.64)$ & $1(0.32)$ & $1(0.32)$ & 0.598 \\
\hline Skin disease & $14(0.50)$ & $17(0.61)$ & $23(0.82)$ & & $2(0.64)$ & $4(1.28)$ & $3(0.96)$ & \\
\hline General & $88(3.17)$ & $103(3.7)$ & $136(4.9)$ & & $25(8.0)$ & $14(4.5)$ & $14(4.5)$ & 0.289 \\
\hline Special & $74(2.66)$ & $14(0.51)$ & $4(0.14)$ & $0.000 *$ & $7(2.24)$ & $2(0.64)$ & $1(0.32)$ & \\
\hline Orthopedics & $15(0.54)$ & $18(0.65)$ & $16(0.57)$ & & $4(1.28)$ & $6(1.92)$ & $2(0.64)$ & \\
\hline Anestrous/RB ${ }^{5}$ & $13(0.47)$ & $28(1.00)$ & $46(1.65)$ & & $1(0.32)$ & $1(0.32)$ & $7(2.24)$ & 0.588 \\
\hline Preg Check ${ }^{6}$ & $5(0.18)$ & $12(0.43)$ & $34(1.22)$ & 0.289 & $3(0.96)$ & $2(0.64)$ & $6(1.92)$ & \\
\hline Mastitis & $6(0.22)$ & $11(0.39)$ & $39(1.40)$ & & $0(0.00)$ & $1(0.32)$ & $5(1.60)$ & \\
\hline Abortion & $1(0.03)$ & $6(0.22)$ & $19(0.68)$ & 0.922 & $0(0.00)$ & $1(0.32)$ & $2(0.64)$ & 0.505 \\
\hline Dystocia & $1(0.03)$ & $4(0.14)$ & $11(0.39)$ & & $0(0.00)$ & $0(0.00)$ & $1(0.32)$ & \\
\hline $\begin{array}{l}\text { Total } 2278 \\
\text { (100) }\end{array}$ & $737(26.5)$ & $\begin{array}{l}986 \\
(35.5)\end{array}$ & $\begin{array}{l}1055 \\
(38.0)\end{array}$ & $\begin{array}{l}102 \\
(32.7)\end{array}$ & $103(33.0)$ & $107(34.3)$ & $\begin{array}{l}312 \\
(100)\end{array}$ & \\
\hline
\end{tabular}

(URTI ${ }^{1}$-Upper Respiratory Tract Infection, $\mathrm{CE}^{2}$-Contagious ecthyma, $\mathrm{MN}^{3}$-Metabolic \& Nutritional diseases, Mus$\mathrm{Ner}^{4}$ - Musculoskeletal and Nervous system, RBS ${ }^{5}$ - Repeat Breeder Syndromes, Preg Check ${ }^{6}$ - Pregnancy Check up *-Significant $\mathrm{P} \leq 0.05$ ). 
Table 3. Sex wise clinical diseases and manifestations of goats and cattle

\begin{tabular}{|c|c|c|c|c|c|c|}
\hline \multirow[b]{2}{*}{ Parameters } & \multicolumn{3}{|c|}{$\begin{array}{c}\text { Total number of goat } \mathrm{N}=2778 \\
\text { No }(\%)\end{array}$} & \multicolumn{3}{|c|}{$\begin{array}{c}\text { Total number of Cattle } \mathrm{N}=312 \\
\text { No }(\%)\end{array}$} \\
\hline & Male & Female & $\begin{array}{c}\mathrm{P}- \\
\text { Value }\end{array}$ & Male & Female & P- Value \\
\hline Weakness & $25(0.90)$ & $52(1.87)$ & 0.323 & $2(0.64)$ & $5(1.60)$ & 0.460 \\
\hline Fattening & $22(0.79)$ & $27(0.97)$ & & $3(0.96)$ & $2(0.64)$ & \\
\hline Idiopathic & $32(1.15)$ & $62(2.23)$ & & $5(1.60)$ & $4(1.28)$ & \\
\hline Loss of appetite & $95(3.42)$ & $149(5.36)$ & 0.067 & $15(4.08)$ & $14(4.49)$ & 0.400 \\
\hline Diarrhea & $48(1.72)$ & $64(3.20)$ & & $4(1.28)$ & $9(2.88)$ & \\
\hline Tympani & $32(1.15)$ & $80(2.88)$ & & $9(2.88)$ & $14(4.49)$ & \\
\hline URTI $^{1}$ & $71(2.55)$ & $115(4.14)$ & 0.219 & $2(0.64)$ & $5(1.60)$ & 0.853 \\
\hline Pneumonia & $37(1.33)$ & $43(1.55)$ & & $2(0.64)$ & $4(1.28)$ & \\
\hline Dysuria & $26(0.94)$ & $25(0.90)$ & & $0(0.00)$ & $4(1.28)$ & \\
\hline Urolithiasis & $38(1.37)$ & $3(0.11)$ & & $0(0.00)$ & $0(0.00)$ & \\
\hline Endoparasite & $118(4.25)$ & $201(7.24)$ & $0.000 *$ & $13(4.17)$ & $12(3.85)$ & 0.504 \\
\hline Ectoparasite & $23(0.83)$ & $30(1.08)$ & & $4(1.28)$ & $1(0.32)$ & \\
\hline Protozoa & $22(0.79)$ & $29(1.04)$ & & $6(1.92)$ & $4(1.28)$ & \\
\hline PPR & $105(3.78)$ & $132(4.75)$ & & \multicolumn{2}{|c|}{ FMD (30) \& wart (1) } & 0.232 \\
\hline $\mathrm{CE}^{2}$ & $5(0.18)$ & $8(0.29)$ & 0.726 & $12(3.85)$ & $18(5.77)$ & \\
\hline Others (Virus) & $5(0.18)$ & $4(0.14)$ & & $1(0.32)$ & $0(0.00)$ & \\
\hline Tetanus & $8(0.29)$ & $6(0.22)$ & & \multicolumn{2}{|c|}{ Anthrax (3) \& others (4) } & 0.155 \\
\hline Foot rot & $5(0.18)$ & $8(0.29)$ & 0.624 & $1(0.32)$ & $2(0.64)$ & \\
\hline Others (Bacteria) & $22(0.79)$ & $24(0.86)$ & & $4(1.28)$ & $0(0.00)$ & \\
\hline $\mathrm{MN}^{3}$ & $29(1.04)$ & $72(2.59)$ & $0.001 *$ & $2(0.64)$ & $5(1.60)$ & 0.853 \\
\hline Mus-Ner ${ }^{4}$ & $33(1.19)$ & $28(1.00)$ & & $2(0.64)$ & $4(1.28)$ & \\
\hline Eye infection & $15(0.54)$ & $42(1.51)$ & $0.010 *$ & $2(0.64)$ & $2(0.64)$ & \\
\hline Skin disease & $27(0.97)$ & $27(0.97)$ & & $4(1.28)$ & $5(1.60)$ & \\
\hline General & $115(4.14)$ & $212(7.63)$ & $0.000 *$ & $27(8.65)$ & $26(8.33)$ & 0.890 \\
\hline Special & $82(2.95)$ & $10(0.36)$ & & $5(1.60)$ & $5(1.60)$ & \\
\hline Orthopedics & $26(0.94)$ & $23(0.83)$ & & $7(2.24)$ & $5(1.60)$ & \\
\hline Anestrous/RB ${ }^{5}$ & 0 & $87(3.13)$ & & $0(0.00)$ & $9(2.88)$ & \\
\hline Preg Check ${ }^{6}$ & 0 & $51(1.84)$ & & $0(0.00)$ & $11(3.53)$ & \\
\hline Mastitis & 0 & $56(2.02)$ & & $0(0.00)$ & $6(1.92)$ & \\
\hline Abortion & 0 & $26(0.94)$ & & $0(0.00)$ & $3(0.96)$ & \\
\hline Dystocia & 0 & $16(0.58)$ & & $0(0.00)$ & $1(0.32)$ & \\
\hline $\begin{array}{l}\text { Total } 2278 \\
(100)\end{array}$ & $\begin{array}{l}1066 \\
(38.37)\end{array}$ & $\begin{array}{l}1712 \\
(61.63)\end{array}$ & & $\begin{array}{l}132 \\
(42.30)\end{array}$ & $\begin{array}{l}180 \\
(57.70)\end{array}$ & \\
\hline
\end{tabular}

(URTI ${ }^{1}$-Upper Respiratory Tract Infection, $\mathrm{CE}^{2}$-Contagius ecthyma, $\mathrm{MN}^{3}$-Metabolic \& Nutritional diseases, Mus-Ner ${ }^{4}$ Musculoskeletal and Nervous system, RBS ${ }^{5}$ - Repeat Breeder Syndromes, Preg Check ${ }^{6}$ - Pregnancy Check up

*-Significant $\mathrm{P} \leq 0.05$ ).

Loss of appetite was the most common owners complain rather than any other diseases and disorders at TVH. In case of respiratory disorders, higher prevalence was found in upper respiratory tract infection in adult goats 94 $(3.38 \%)$ rather than young and old over the pneumonia with significant $\mathrm{P}$ value $(\mathrm{P}=0.041)$. In case of bacterial infection, prevalence of others bacterial diseases in adult goats were higher than young and old over the tetanus and foot rots with the significant $\mathrm{P}$ value $(\mathrm{P}=0.000)$. 


\section{A. Parvez and others}

The results showed that the prevalence of metabolic and nutritional diseases was high in old 40(1.43\%) and adult goats $36(1.29 \%)$ and low in kid $25(0.90 \%)$ over the musculoskeletal and nervous disorders with significant $\mathrm{P}$ value $(\mathrm{P}=0.030)$.In case of surgical cases, higher prevalence was found in general surgical cases in old goats 136 $(4.9 \%)$ and adult goats $103(3.7 \%)$ than young goats 88 (3.17) over the special and orthopedic surgical conditions with significant $\mathrm{P}$ value $(\mathrm{P}=0.000)$.

Prevalence of clinical diseases and disorders in goats and cattle in relation with their sex revealed that highest numbers of female animals (goats $61.63 \%$ and cattle $57.70 \%$ ) followed by male animals (goats $38.37 \%$ and cattle $42.30 \%$ ) were admitted at TVH during the period of 2012. So that result revealed that there was highest and significant number female goats and cattle were registered over the male goats and cattle (Table-3) agreed with results of Kabir et al. (2010). The prevalence of urolithiasis was higher in male goat 38 (1.37\%) than female goats over dysuria with significant $\mathrm{P}$ value $(\mathrm{P}=0.000)$. The observations of the present study showed that the prevalence of metabolic and nutritional diseases was higher in female goats $72(2.59 \%)$ than male goats 29 $(1.04 \%)$ over the musculoskeletal and nervous disorders with significant $\mathrm{P}$ value $(\mathrm{P}=0.001)$ due to no supplementation of vitamin mineral to old and adult animals were given to study area. Diseases of special sense organs results revealed that the prevalence of eye infection was higher in female goats 42 (1.51) than male goats $15(0.54 \%)$ over the skin diseases with significant $\mathrm{P}$ value $(\mathrm{P}=0.010)$. In case of surgical cases higher prevalence was found in female goats in general surgery 212 (7.63\%) than male goats $115(4.14 \%)$ over special and orthopedic surgery with significant $\mathrm{P}$ value $(\mathrm{P}=0.000)$. In case of gynae-obstetrical cases, high prevalence were found in anestrous/repeat breeder syndromes (goats $3.13 \%$ and cattle $2.88 \%$ ) followed by pregnancy check up (goats $1.84 \%$ cattle $3.53 \%$ ), mastitis (goats $2.02 \%$ and cattle $1.92 \%$ ) and lest prevalence was found in obstetrical cases, abortion (goats $0.94 \%$ and cattle $0.96 \%$ ) and dystocia (goats $0.58 \%$ and cattle $0.32 \%$ ) due to negative energy balance of feed most of the animal do not show heat after parturition or in young.

Prevalence of clinical diseases and disorders in goats and cattle due to seasonal variation revealed that highest prevalence was found in rainy season (goats $38.80 \%$ and cattle $34.30 \%$ ) followed by summer (goats $29.77 \%$ and cattle $33.33 \%$ ) and winter (goats $31.43 \%$ and cattle 32.37\%) (Table-4) agreed with the findings of Rahman et al. (2012) who showed that highest prevalence of clinical diseases and disorders in goats and cattle were found in rainy and winter season in compare to summer seasons due to after rainy season soil borne and parasitic disease condition might be aggravated and in case of winter most of the animal gather together in a shed. Among of the medicinal cases, the results showed that the highest prevalence of endoparasitic diseases were found in goats 163 $(5.9 \%)$ in rainy season in compare to ectoparasitic and protazoal diseases over summer and winter season with the significant $\mathrm{p}$ value $(\mathrm{p}=0.000)$, followed by idiopathic causes of diseases $44(1.58 \%)$ with significant $\mathrm{p}$ value $(\mathrm{p}=0.000)$, loss of appetite $101(3.6 \%)$ with significant $\mathrm{p}$ value $(\mathrm{p}=0.000)$, upper respiratory tract infection $74(2.66 \%)$ with significant $\mathrm{p}$ value $(\mathrm{p}=0.001)$ and diseases of skin $28(1.00 \%)$ with significant $\mathrm{p}$ value $(\mathrm{p}=0.018)$ in goats during rainy season. Prevalence of dysuria in goat 24(0.86\%) in winter season and urolithiasis $21(0.76 \%)$ in summer seasons with significant $\mathrm{p}$ value $(\mathrm{p}=0.025)$. In case of surgical cases, highest prevalence was found in general surgery in goats $139(5.0 \%)$ with significant $\mathrm{p}$ value $(\mathrm{P}=0.005)$. In case of gyne-obstetrics, highest prevalence was found in anestrous/ repeate breeder syndromes 44 (1.58) and pregnancy check up $22(0.79 \%)$ in goats during rainy season but $\mathrm{p}$ value was not significant $(\mathrm{P}=0.216)$. In case of obstetrical cases abortion rate was higher in goats $13(0.47 \%)$ during winter season with significant $\mathrm{p}$ value $(\mathrm{P}=0.016)$.

Prevalence of clinical diseases and disorders in goats and cattle in relation with the breeds revealed that highest clinical conditions were found in Black Bangle goat 1157(41.65\%) and local breeds of cattle $192(61.54 \%)$ followed by Jamunapari goat $878(31.60 \%)$ and cross breeds of cattle $120(38.46 \%)$ and cross breeds of goats $743(76.75 \%)$ due to black bangle goats are commonly known as poor man cows (Table-5). Among of the medicinal cases higher prevalence was found in loss of appetite in Black Bangle goats 87(3.13\%) than other clinical conditions diarrhea and tymapni over tha Jamunapari goats and other cross breeds goats with significant $\mathrm{P}$ value $(\mathrm{P}=0.002)$. The prevalence of eye infection was higher in Black Bangle goats $34(1.22 \%)$ than skin diseases over the Jamunapari goats and other cross breeds goats with significant $\mathrm{p}$ value $(\mathrm{P}=0.021)$. In case of viral disease higher prevenlce was found in PPR in Black Bangle goats 109 (3.92\%) than Jamunapari goats 66 $(2.37 \%)$ and cross breeds goats $62(2.33 \%)$, but in case of cattle higher prevalence was found in FMD virus in local indigenous cattle $20(6.41 \%)$ than cross breeds cattle $10(3.21 \%)$ but p value was not significant in both cases of viral diseases. Among of the surgical cases, higher prevalence of general surgery was performed in Black 
Bangle goats $128(4.60 \%)$ than Jamunapari goats and other cross breeds goats over the special and orthopedic surgery with significant $\mathrm{P}$ value $(\mathrm{P}=0.010)$.

Table 4. Season wise clinical diseases and manifestations of goats and cattle

\begin{tabular}{|c|c|c|c|c|c|c|c|c|}
\hline \multirow[b]{2}{*}{ Parameters } & \multicolumn{4}{|c|}{$\begin{array}{c}\text { Total number of goat } \mathrm{N}=2778 \\
\text { No }(\%)\end{array}$} & \multicolumn{4}{|c|}{$\begin{array}{c}\text { Total number of Cattle } \mathrm{N}=312 \\
\text { No }(\%)\end{array}$} \\
\hline & Summer & Rainy & Winter & $\begin{array}{l}\mathrm{P}- \\
\text { Value }\end{array}$ & Summer & Rainy & Winter & $\begin{array}{l}\text { P- } \\
\text { Value }\end{array}$ \\
\hline Weakness & $25(0.90)$ & $12(0.43)$ & $40(1.44)$ & $0.000^{*}$ & $2(0.64)$ & $2(0.64)$ & $3(0.96)$ & 0.473 \\
\hline Fattening & $17(0.61)$ & $17(0.61)$ & $15(0.54)$ & & $3(0.96)$ & $0(0.00)$ & $2(0.64)$ & \\
\hline Idiopathic & $22(0.79)$ & $44(1.58)$ & $28(1.01)$ & & $6(1.92)$ & $1(0.32)$ & $2(0.64)$ & \\
\hline Loss of appetite & $87(3.13)$ & $101(3.6)$ & $56(2.02)$ & $0.000 *$ & $11(3.5)$ & $9(2.88)$ & $9(2.88)$ & 0.221 \\
\hline Diarrhea & $25(0.90)$ & $45(1.62)$ & $42(1.51)$ & & $2(0.64)$ & $4(1.28)$ & $7(2.24)$ & \\
\hline Tympani & $40(1.44)$ & $24(0.86)$ & $48(1.73)$ & & $3(0.96)$ & $10(3.2)$ & $10(3.2)$ & \\
\hline URTI $^{1}$ & $42(1.51)$ & $74(2.66)$ & $70(2.52)$ & $0.001 *$ & $1(0.32)$ & $4(1.28)$ & $2(0.64)$ & 0.672 \\
\hline Pneumonia & $34(1.22)$ & $30(1.08)$ & $16(0.58)$ & & $1(0.32)$ & $2(0.64)$ & $3(0.96)$ & \\
\hline Dysuria & $14(0.50)$ & $13(0.47)$ & $24(0.86)$ & $0.025^{*}$ & $1(0.32)$ & $3(0.96)$ & $0(0.00)$ & \\
\hline Urolithiasis & $21(0.76)$ & $11(0.40)$ & $9(0.32)$ & & $0(0.00)$ & $0(0.00)$ & $0(0.00)$ & \\
\hline Endoparasite & $72(2.59)$ & $163(5.9)$ & $84(3.02)$ & $0.000 *$ & $5(1.60)$ & $12(3.8)$ & $8(2.56)$ & 0.670 \\
\hline Ectoparasite & $31(1.12)$ & $10(0.36)$ & $12(0.43)$ & & $2(0.64)$ & $2(0.64)$ & $1(0.32)$ & \\
\hline Protozoa & $16(0.58)$ & $27(0.97)$ & $8(0.29)$ & & $2(0.64)$ & $3(0.96)$ & $5(1.6)$ & \\
\hline PPR & $59(2.12)$ & $97(3.49)$ & $81(2.91)$ & 0.909 & \multicolumn{3}{|c|}{ FMD (30) \& wart (1) } & 0.391 \\
\hline $\mathrm{CE}^{2}$ & $2(0.07)$ & $6(0.22)$ & $5(0.18)$ & & $9(2.88)$ & $10(3.2)$ & $11(3.5)$ & \\
\hline Others (Virus) & $2(0.07)$ & $3(0.11)$ & $4(0.14)$ & & $0(0.00)$ & $1(0.32)$ & $0(0.00)$ & \\
\hline Tetanus & $1(0.04)$ & $6(0.22)$ & $7(0.25)$ & 0.220 & \multicolumn{3}{|c|}{ Anthrax (3) \& others (4) } & 0.327 \\
\hline Foot rot & $5(0.18)$ & $4(0.14)$ & $4(0.14)$ & & $2(0.64)$ & $0(0.00)$ & $1(0.32)$ & \\
\hline $\begin{array}{l}\text { Others } \\
\text { (Bacteria) }\end{array}$ & $11(0.40)$ & $23(0.83)$ & $12(0.43)$ & & $1(0.32)$ & $2(0.64)$ & $1(0.32)$ & \\
\hline $\mathrm{MN}^{3}$ & $42(1.51)$ & $34(1.22)$ & $25(0.90)$ & 0.284 & $2(0.64)$ & $5(1.60)$ & $0(0.00)$ & 0.429 \\
\hline Mus-Ner ${ }^{4}$ & $20(0.72)$ & $19(0.68)$ & $22(0.79)$ & & $3(0.96)$ & $3(0.96)$ & $0(0.00)$ & \\
\hline Eye infection & $12(0.43)$ & $18(0.65)$ & $27(0.97)$ & $0.018 *$ & $2(0.64)$ & $2(0.64)$ & $0(0.00)$ & 0.263 \\
\hline Skin disease & $14(0.50)$ & $28(1.00)$ & $12(0.43)$ & & $2(0.64)$ & $3(0.96)$ & $4(1.28)$ & \\
\hline General & $90(3.24)$ & $139(5.0)$ & $98(3.53)$ & $0.005^{*}$ & $24(7.7)$ & $16(5.1)$ & $13(4.2)$ & 0.482 \\
\hline Special & $39(1.40)$ & $22(0.79)$ & $31(1.12)$ & & $2(0.64)$ & $3(0.96)$ & $5(1.60)$ & \\
\hline Orthopedics & $18(0.65)$ & $13(0.47)$ & $18(0.65)$ & & $4(1.28)$ & $4(1.28)$ & $4(1.28)$ & \\
\hline Anestrous/RB ${ }^{5}$ & $24(0.86)$ & 44 (1.58) & $19(0.68)$ & 0.216 & $4(1.28)$ & $1(0.32)$ & $4(1.28)$ & 0.952 \\
\hline Preg Check ${ }^{6}$ & $15(0.54)$ & $22(0.79)$ & $14(0.50)$ & & $7(2.24)$ & $2(0.64)$ & $3(0.96)$ & \\
\hline Mastitis & $17(0.61)$ & $18(0.65)$ & $21(0.76)$ & & $3(0.96)$ & $1(0.32)$ & $2(0.64)$ & \\
\hline Abortion & $3(0.11)$ & $10(0.36)$ & $13(0.47)$ & $0.016^{*}$ & $1(0.32)$ & $1(0.32)$ & $1(0.32)$ & 0.513 \\
\hline Dystocia & $7(0.25)$ & $1(0.04)$ & $8(0.29)$ & & $0(0.00)$ & $1(0.32)$ & $0(0.00)$ & \\
\hline $\begin{array}{l}\text { Total } 2278 \\
\text { (100) }\end{array}$ & $\begin{array}{l}827 \\
(29.77)\end{array}$ & $\begin{array}{l}1078 \\
(38.80)\end{array}$ & $\begin{array}{l}873 \\
(31.43)\end{array}$ & & $\begin{array}{l}104 \\
(33.33)\end{array}$ & $\begin{array}{l}\mathbf{1 0 7} \\
(34.30)\end{array}$ & $\begin{array}{l}101 \\
(32.37)\end{array}$ & \\
\hline
\end{tabular}

(URTI ${ }^{1}$-Upper Respiratory Tract Infection, $\mathrm{CE}^{2}$-Contagious ecthyma, $\mathrm{MN}^{3}$-Metabolic \& Nutritional diseases, MusNer ${ }^{4}$ - Musculoskeletal and Nervous system, RBS $^{5}$ - Repeat Breeder Syndromes, Preg Check ${ }^{6}$ - Pregnancy Check up $*_{\text {-Significant } \mathrm{P} \leq 0.05 \text { ) }}$

The result of this study showed that digestive disorders, parasitic diseases and general surgical cases are predominantly present in goats and cattle among of the other medicinal and surgical cases. Proper feeding, housing, deworming, vaccination and management is therefore necessary for the development of goats and cattle industry in our country. The knowledge derived from this study will increase our understanding the clinical 


\section{A. Parvez and others}

diseases and disorders in goats and cattle in a particular area and taking necessary preventive measure against these diseases and disorders at national policy level.

Table 5. Breed wise clinical diseases and manifestations of goats and cattle

\begin{tabular}{|c|c|c|c|c|c|c|c|}
\hline \multirow[b]{2}{*}{ Parameters } & \multicolumn{4}{|c|}{$\begin{array}{l}\text { Total number of goat } \mathrm{N}=2778 \\
\text { No }(\%)\end{array}$} & \multicolumn{3}{|c|}{$\begin{array}{c}\text { Total number of Cattle } \mathrm{N}=312 \\
\text { No }(\%)\end{array}$} \\
\hline & $\begin{array}{l}\text { Black } \\
\text { Bangle }\end{array}$ & Jamunapari & Cross & P-Value & $\begin{array}{l}\text { Local } \\
\text { breed }\end{array}$ & $\begin{array}{l}\text { Exotic } \\
\text { breed }\end{array}$ & P- Value \\
\hline Weakness & $31(1.12)$ & $26(0.94)$ & $20(0.72)$ & 0.737 & $5(1.60)$ & $2(0.64)$ & 0.780 \\
\hline Fattening & $25(0.90)$ & $15(0.54)$ & $9(0.32)$ & & $3(0.96)$ & $2(0.64)$ & \\
\hline Idiopathic & $45(1.62)$ & $27(0.97)$ & $22(0.79)$ & & $7(2.24)$ & $2(0.64)$ & \\
\hline Loss of appetite & $87(3.13)$ & $76(2.74)$ & $81(2.92)$ & $0.002 *$ & $21(6.73)$ & $8(2.56)$ & 0.734 \\
\hline Diarrhea & $48(1.73)$ & $46(1.66)$ & $18(0.65)$ & & $10(3.21)$ & $3(0.96)$ & \\
\hline Tympani & $55(1.98)$ & $34(1.22)$ & $23(0.83)$ & & $15(4.81)$ & $8(2.56)$ & \\
\hline URTI $^{1}$ & $78(2.81)$ & $55(1.98)$ & $53(1.91)$ & 0.170 & $2(0.64)$ & $5(1.60)$ & 0.429 \\
\hline Pneumonia & $34(1.22)$ & $31(1.11)$ & $15(0.54)$ & & $3(0.96)$ & $3(0.96)$ & \\
\hline Dysuria & $22(0.79)$ & $16(0.57)$ & $13(0.47)$ & 0.773 & $4(1.28)$ & $0(0.00)$ & \\
\hline Urolithiasis & $20(0.72)$ & $13(0.47)$ & $8(0.29)$ & & $0(0.00)$ & $0(0.00)$ & \\
\hline Endoparasite & $102(3.67)$ & $119(4.3)$ & $98(3.53)$ & 0.678 & $13(4.17)$ & $12(3.85)$ & 0.504 \\
\hline Ectoparasite & $19(0.68)$ & $21(0.76)$ & $13(0.47)$ & & $4(1.28)$ & $1(0.32)$ & \\
\hline Protozoa & $20(0.72)$ & $15(0.54)$ & $16(0.57)$ & & $6(1.92)$ & $4(1.28)$ & \\
\hline PPR & $109(3.92)$ & $66(2.37)$ & $62(2.23)$ & 0.118 & \multicolumn{2}{|c|}{ FMD (30)\& wart (1) } & 0.483 \\
\hline $\mathrm{CE}^{2}$ & $9(0.32)$ & $3(0.11)$ & $1(0.04)$ & & $20(6.41)$ & $10(3.21)$ & \\
\hline Others (Virus) & $7(0.25)$ & $0(0.00)$ & $2(0.07)$ & & $1(0.32)$ & $0(0.00)$ & \\
\hline Tetanus & $7(0.25)$ & $5(0.18)$ & $2(0.07)$ & 0.820 & \multicolumn{2}{|c|}{ Anthrax (3) \& others (4) } & 0.147 \\
\hline Foot rot & $5(0.18)$ & $4(0.14)$ & $4(0.14)$ & & $3(0.96)$ & $2(0.64)$ & \\
\hline $\begin{array}{l}\text { Others } \\
\text { (Bacteria) }\end{array}$ & $19(0.68)$ & $13(0.47)$ & $14(0.50)$ & & $0(0.00)$ & $2(0.64)$ & \\
\hline $\mathrm{MN}^{3}$ & $40(1.44)$ & $35(1.26)$ & $26(0.94)$ & 0.931 & $4(1.28)$ & $3(0.96)$ & 0.391 \\
\hline Mus-Ner ${ }^{4}$ & $26(0.94)$ & $20(0.72)$ & $15(0.54)$ & & $2(0.64)$ & $4(1.28)$ & \\
\hline Eye infection & $34(1.22)$ & $8(0.29)$ & $15(0.54)$ & $0.021 *$ & $2(0.64)$ & $2(0.64)$ & 0.569 \\
\hline Skin disease & $19(0.68)$ & $17(0.61)$ & $18(0.65)$ & & $3(0.96)$ & $6(1.92)$ & \\
\hline General & $128(4.60)$ & $103(3.7)$ & $96(3.45)$ & $0.010 *$ & $30(9.62)$ & $23(7.37)$ & 0.380 \\
\hline Special & $51(1.84)$ & $21(0.76)$ & $20(0.72)$ & & $8(2.56)$ & $2(0.64)$ & \\
\hline Orthopedics & $24(0.86)$ & $19(0.68)$ & $6(0.22)$ & & $7(2.24)$ & $5(1.60)$ & \\
\hline Anestrous/RB ${ }^{5}$ & $28(1.00)$ & $30(1.08)$ & $29(1.04)$ & 0.945 & $5(1.60)$ & $4(1.28)$ & 0.590 \\
\hline Preg Check ${ }^{6}$ & $18(0.65)$ & $15(0.54)$ & $18(0.65)$ & & $8(2.56)$ & $3(0.96)$ & \\
\hline Mastitis & $21(0.76)$ & $18(0.65)$ & $17(0.61)$ & & $3(0.96)$ & $3(0.96)$ & \\
\hline Abortion & $14(0.50)$ & $5(0.18)$ & $7(0.25)$ & 0.378 & $2(0.64)$ & $1(0.32)$ & 0.505 \\
\hline Dystocia & $12(0.43)$ & $2(0.07)$ & $2(0.07)$ & & $1(0.32)$ & $0(0.00)$ & \\
\hline $\begin{array}{l}\text { Total } 2278 \\
\text { (100) }\end{array}$ & $\begin{array}{l}1157 \\
(41.65)\end{array}$ & $878(31.60)$ & $\begin{array}{l}743 \\
(26.75)\end{array}$ & & $\begin{array}{l}192 \\
(61.54)\end{array}$ & $\begin{array}{l}120 \\
(38.46)\end{array}$ & \\
\hline
\end{tabular}

(URTI ${ }^{1}$-Upper Respiratory Tract Infection, $\mathrm{CE}^{2}$-Contagious ecthyma, $\mathrm{MN}^{3}$-Metabolic \& Nutritional diseases, Mus$\mathrm{Ner}^{4}-$ Musculoskeletal and Nervous system, RBS $^{5}$ - Repeat Breeder Syndromes, Preg Check ${ }^{6}$ - Pregnancy Check up $*_{\text {-Significant } \mathrm{P} \leq 0.05 \text { ) }}$

\section{ACKNOWLEDGEMENT}

The authors are grateful to the Department of Medicine Surgery, Shahedul Alam Quadery teaching veterinary hospital and students of $15^{\text {th }}$ batch, Chittagong Veterinary and Animal Sciences University, Khulshi-4225, Chittagong, Bangladesh for their kind co-operation during the research period. 
Clinical diseases and manifestations of goats and cattle

\section{REFERENCES}

1. BBS (2008). Statistical year book on Bangladesh. Bangladesh Bureau Statistics, Ministry of Planning, Dhaka.

2. DLS (2008-09). Annual Report of Directorate of Livestock Services, Bangladesh.

3. Kabir MH, Reza MA, Razi KMA, Parvez MM, Bag MAS and Mahfuz SU (2010). A report on clinicalprevalence of diseases and disorders in cattle and goat at the Upazilla Veterinary Hospital, Ulipur, Kurigram. Internatioal Journal of BioResearch 2: 17-23.

4. Pallab MS, Ullah SM, Uddin MM and Miazi OF (2012). A cross sectional study of several diseases in cattle at Chandanaish Upazilla of Chittagong district, Bangladesh. Scientific Journal of Veterinary Advances 1: 28-32.

5. Rahman MA, Islam MA, Rahman MA, Talukder AK, Parvin MS and Islam MT (2012). Clinical diseases of ruminants recorded at the Patuakhali Science and Technology University Veterinary Clinic. Bangladesh Journal of Veterinary Medicine 10 (1\&2): 63-73.

6. Samad MA (2001). Observations of clinical diseases in ruminants at the Bangladesh Agricultural University Veterinary Clinic. Bangladesh Veterinary Journal 35: 93-120.

7. Samad MA, Islam MA and Hossain A (2002). Patterns of occurrence of calf diseases in the district of Mymensingh in Bangladesh. Bangladesh Veterinary Journal 36: 01-05. 